Discussion Paper No. 07-073

\title{
Spillovers of Innovation Activities and Their Profitability
}

Dirk Czarnitzki and Kornelius Kraft

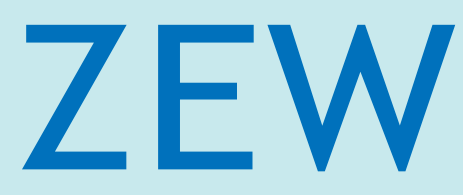

Zentrum für Europäische Wirtschaftsforschung $\mathrm{GmbH}$

Centre for European

Economic Research 
Discussion Paper No. 07-073

\section{Spillovers of Innovation Activities and Their Profitability}

Dirk Czarnitzki and Kornelius Kraft

Download this ZEW Discussion Paper from our ftp server:

ftp://ftp.zew.de/pub/zew-docs/dp/dp07073.pdf

Die Discussion Papers dienen einer möglichst schnellen Verbreitung von neueren Forschungsarbeiten des ZEW. Die Beiträge liegen in alleiniger Verantwortung der Autoren und stellen nicht notwendigerweise die Meinung des ZEW dar.

Discussion Papers are intended to make results of ZEW research promptly available to other economists in order to encourage discussion and suggestions for revisions. The authors are solely responsible for the contents which do not necessarily represent the opinion of the ZEW. 


\section{Non-technical Summary}

Spillovers of innovation activities have been discussed in the economic literature for several decades. The key argument by Arrow (1962) relies on the fact that research and development $(R \& D)$ activities of firms generate positive external effects. R\&D implies the creation of knowledge which is the most intangible asset of a firm. However, knowledge can hardly be kept secret and will spill over to third parties. Spillovers to competitors have possibly been the most discussed knowledge transfer channel in industrial economic literature since then. As rivals may be able to use information generated in other companies, the inventor cannot appropriate all returns from $R \& D$ activities, and thus the social benefit of R\&D will be considerably larger then the private one. Hence, spillovers going to rivals affect profitability negatively as this information benefits direct competitors. In contrast, incoming spillovers have a positive impact on profits, as the firm is able to use information without paying for it.

Although spillovers have been widely discussed in both theoretical and empirical literature, most studies assume symmetry of the effect of incoming and outgoing spillovers. While several empirical studies dealt with spillovers and their effect on the propensity to engage in $R \& D$ collaboration, there is no study that allows for asymmetric effects with respect to firms' profitability. We use survey data that enable us to account for potential asymmetries between incoming and outgoing spillovers.

Our empirical study considers innovating firms in German manufacturing. It turns out that incoming spillovers of rivals have a positive effect on profitability on top of a firm's own R\&D investment. However, this effect cannot be interpreted independently of outgoing spillovers. If knowledge flows relatively freely within an industry, many firms will benefit from spillovers and thus the recipient of a spillover is not able to achieve a comparative advantage. Indeed, we find that profits are lower in industries where outgoing spillovers are high. Our results also suggest that firms can countervail the information leakage through patenting. Firms holding patents achieve a profit premium due to their intellectual property as this prevents rivals from using knowledge spillovers to some extent, at least. 


\title{
Spillovers of Innovation Activities and Their Profitability
}

\author{
Dirk Czarnitzki ${ }^{\text {a,c,d }}$ and Kornelius Kraft ${ }^{\text {b,d }}$ \\ ${ }^{a}$ K.U.Leuven, Dept. of Managerial Economics, Strategy and Innovation \\ ${ }^{b}$ University of Dortmund, Dept. of Economics \\ ${ }^{c}$ Steunpunt O\&O Indicatoren at K.U.Leuven \\ ${ }^{d}$ Centre for European Economic Research (ZEW), Mannheim
}

October 2007

\begin{abstract}
Knowledge spillovers to competitors are regarded as an important aspect of the innovation process. While a company possibly benefits from incoming information on successful R\&D conducted by other companies, a generally high probability of leakage of knowledge in an industry will negatively affect profitability. This paper presents the results of an empirical study on the effects of outgoing and incoming spillovers on firms' profitability. It turns out that the expected asymmetry is actually at work. In contrast to spillovers from competitors, spillovers from suppliers, customers and research institutions exert no effect.
\end{abstract}

Keywords: Innovation, Spillover, Profitability.

JEL-Classification: L12, O31, O32

Address: Dirk Czarnitzki

\section{K.U.Leuven}

Dept. of Managerial Economics, Strategy and Innovation

Naamsestraat 69

3000 Leuven

Belgium

Phone: +3216326906

E-Mail:_dirk.czarnitzki@econ.kuleuven.be
Kornelius Kraft

University of Dortmund

Dept. of Economics

Vogelpothsweg 87

44227 Dortmund

Germany

+49 231 755-3152

kornelius.kraft@uni-dortmund.de

Acknowledgement: We thank the ZEW team of the Mannheim Innovation Panel for making their survey data available. 


\section{Introduction}

Innovation is the efficient use of the scarce resource knowledge. Knowledge in turn is the result of a firm's own R\&D or information spillovers from outside. Information spillover possibly result i.e. from reseach activities conducted by research institutions, suppliers or customers but the most important source is perhaps information from competing companies. The latter flows of knowledge have been an important topic in the discussion on innovation. Arrow (1962) maintained that the existence of spillovers will lead to underinvestement into $R \& D$ because the returns of these investments are partly appropriated by competitors. An important contribution to this literature is d'Aspremont and Jaquemin (1988) who consider the effects of spillovers on the incentives to conduct $R \& D$ as well as the incentives to form $R \& D$ joint ventures. The term "spillover" is used for the involuntary leakage of knowledge and sometimes also for voluntary exchange of information through research joint ventures. Incoming spillovers are expected to have a positive impact on profits, as the firm is able to use information without paying for it. In contrast, spillovers going to rivals will possibly negatively affect profitability as this information benefits direct competitors.

The industrial organization literature mostly considers symmetric spillovers typically in a duopoly model of cost-saving (process) innovation in the spirit of d'Aspremont and Jaquemin (1988). However, it is by no means clear that symmetric spillovers are realistic. In practice the possibilities of firms to keep the outcome of their innovation activites secret may differ and the degree of appropriability of technological knowledge by patents varies across industries. Perhaps most importantly, different spillover effects may result from differences in firm-specific absorptive capacities (Cohen and Levinthal 1989). There exist a few models, like de Bondt and Henriques (1995), Amir and Wooders (2000), Atallah (2005) or Vandekerckhove and De Bondt (2007) which include asymmetries in spillovers. Most of these models assume that aside of the spillover asymmetry the firms are similar and equilibrium is calculated by determining output à la Cournot. Vandekerckhove and De Bondt (2007) distinguish market leaders and followers and differentiate spillovers as leader-specific spillovers, follower specific spillovers, spillovers from leaders to followers and spillovers from followers to leaders. 
Spillovers are also an issue in the empirical literature. Technological activites of others are either captured by R\&D or patenting at the industry level (sometimes weighted by technological distance), or scholars have used survey data. ${ }^{1}$ Basically two approaches are used. On the one hand, production or profit functions including a measure of knowledge capital are estimated. This knowledge capital is computed on the basis of the firms’ own $R \& D$ and $R \& D$ expenditures by other companies, as the firm may learn from other firms' innovations which is captured by the second component of the knowledge capital. The external source is either measured as the industry's total expenditures exluding the firm in question (a recent example is Ornaghi, 2006) or by calculating a weighting matrix based on the distance in technology space (Jaffe 1986, Hanel and StPierre 2003). Griliches (1998) notes that it is not easy to distinguish a spillover from the alternative interpretation that the positive coefficent just reflects the existence of correlated technical opportunities. Hitt and Tambe (2007) explicitly discuss the possible bias if spillovers are estimated by knowledge capital of other firms.

As just one coefficient of the relevant variables is estimated, the "industry approach" necessarily assumes that spillovers are symmetric and have the same impact for all firms. International spillovers are usually not taken into account. Mostly, just one source of spillovers, e.g. based R\&D expenditures, are used, but Bloom et al. (2005) differentiate between two kinds of technology spillovers. On the one hand, spillovers from technologically close firms increase the productivity of other firms which operate in similar technology areas. The "neighbors" in technological terms must not necessarily be at the same time "neighbors" in the product market. While spillovers from technologically similar firms are beneficial, $R \& D$ activity by product market rivals has a negative effect.

The second method is based on survey evidence. Firms are asked to assess how important external information is for them. This information is then used to explain R\&D intensities, the development of innovations and perhaps profitability. Examples of empirical studies of this kind are Cassiman and Veugelers (2002), Belderbos et.al. (2004), Schmidt (2005), Veugelers and Cassiman (2005) as well as Vencatachellum and

\footnotetext{
${ }^{1}$ Surveys on the earlier literature concerning spillovers are Griliches (1992) and Nadiri (1993).
} 
Versaevel (2006), which all investigate the relation between spillovers and the likelihood of engaging in $R \& D$ cooperations.

Despite the fact that their existence is quite realistic in practice, asymmetric spillovers are hardly considered in empirical research explaining profitability. We use survey data that include not only knowledge flows from competitors but the survey in addition asks with respect to information from research institutions, suppliers and customers. In our view, survey data have several advantages: as the firms assess the importance of incoming spillovers, they themselves indicate the relevance of external knowledge for their company. Thus, this information can be used to define asymmetries between firms in that some benefit more from external sources than others. We would also like to point out that the spillovers indicated in survey data are not restricted to the domestic market only as in the more widely used "industry approach" where R\&D spillovers are typically calculated only from R\&D data of domestic firms.

The following section describes our conceptual framework for our study on the effects of incoming and outgoing spillovers for profitability, and section 3 presents the results. The final section concludes.

\section{Conceptional Framework and Data}

The purpose of our empirical test is to discriminate between the individual degree of spillovers measured at the firm level and the industry-wide degree of spillovers. We use survey data in order to determine how relevant spillovers are to a particular firm's profitability. The firms have to rate the importance of information flows coming in from several sources. One of the possible origins of spillovers are competitors. The survey method has its advantage by taking into account that firms may benefit to a different extent from spillovers. As firms indicate if spillovers were important or not, asymmetries between the relevance of these spillovers are implied by construction. We expect that incoming spillovers have a positive impact on profits.

Following Belderbos et al. (2003) as well as Vencatachellum and Versaevel (2006), the average degree of knowledge spillovers relevant for the industry as a whole is taken as the indicator for the risk of leakage of information to other producers. Thus, we use the industry average as a proxy variable for outgoing spillovers for a firm in the 
corresponding industry. Unlike incoming spillovers, the industry averaged spillovers indicating that firms cannot appropriate all return from innovation privately should have a negative effect on profits of a firm. In our view it is important to separate these two kinds of spillovers as $R \& D$ improves the competiveness of a firm and at the same time may reduce the profits of the rivals even if some information leaks out. If spillovers are quite large, however, the research active firm will perhaps earn less than the free riding competitor.

Aside from spillovers from rivals, we consider information flows from suppliers, customers and research institutions. If a firm indicates that it receives important information from these sources, we expect to estimate a positive coefficient. In contrast, the industry average shows the benefits to the competitors and therefore a negative coefficient is plausible.

Our study is based on a sample of German firms surveyed in the year 2003, that is, the data correspond to the time period 2000-2002. The firm-level survey information stems from the Mannheim Innovation Panel (MIP). The MIP is an innovation survey conducted by the Centre for European Economic Research (ZEW), Mannheim, on behalf of the German Federal Ministry for Education and Research (BMBF) and is carried out annually since $1992 .^{2}$ However, the question regarding the return on sales was only introduced in the 2003 spell, and therefore we have to rely on a single crosssection. The MIP covers firms in the manufacturing sector with more than 5 employees. $^{3}$ As we are interested in the effect of spillovers resulting from innovation activity, we restrict our sample to innovating firms, that is, we end up with a sample of 903 firms that did either introduce at least one new product in the market, or implemented a new process in their production between 2000 and 2002.

\section{Dependent variable}

2 In 1993, 1997, 2001, 2004 and 2005 the MIP represented the German part of the Community Innovation Survey (CIS), a harmonized innovation survey across all EU Member States and Norway as well as Switzerland.

3 A few firms are actually smaller than five employees due to differences between the population database used for drawing the sample of the MIP and the firms' response in the questionnaire. 
The dependent variable is the profit margin. This variable is sometimes called excess return on sales and expresses the following:

$$
\frac{\pi}{S}=\frac{S \text { - labor cost }- \text { capital cost }- \text { material cost }}{S}
$$

with $\pi$ denoting profits and $S$ being sales. If firms are in the long-run equilibrium and are operating in the range of their production functions with constant returns to scale, the excess profit return on sales will, on average across all products produced by the firm, equal the Lerner index. With constant returns to scale, marginal costs $(M C)$ are equal to average costs $(A C)$. One can therefore write:

$$
\frac{\pi}{S}=\frac{p q-A C q}{p q}=\frac{p-M C}{p}
$$

with $p$ being the price and $q$ the quantity produced. ${ }^{4}$ As a question on return on investment is typically considered as sensitive information, and the likelihood of item non-response may be high, the return on sales variable was surveyed as a categorical variable and Table 1 shows the definition of the classes.

Table 1: Surveyed categories of the return on sales

\begin{tabular}{cccccc}
\hline Return on sales & Class & Return on sales & Class & Return on sales & Class \\
\hline$<0 \%$ & 0 & $(4-7 \%]$ & 3 & $>15 \%$ & 6 \\
$(0-2 \%]$ & 1 & $(7-10 \%]$ & 4 & "don't know" & 7 \\
$(2-4 \%]$ & 2 & $(10-15 \%]$ & 5 & missing value* & 8
\end{tabular}

* Although the firms had the possibility to respond "don't know", there were also several cases where the respondent did not respond at all to the question.

The intial sample of innovating firms amounted to 1,051 firms. Figure 1 shows the distribution of responses. As expected there are quite some missing values in the variable. Fourty-four respondents indicated “don’t know” and 104 did not at all respond to the questions. Also note that 154 report that they have a negative rate of return which

\footnotetext{
${ }^{4}$ Note that scholars often used an empirical approximation of the price-cost margin as introduced by Collins and Preston (1969) as well as Ravenscraft and Scherer (1982). Typically, it was computed as (sales - staff cost - material cost) / sales. As this measure did not take the user cost of capital into account, scholars included capital divided by sales as an explanatory variable on the right hand side of their regression to correct this bias. As we have surveyed the return on sales directly, we do not have to account for missing capital cost.
} 
corresponds to $17 \%$ of observations of our final sample of 903 firms. The modus is a rate of return between four and seven percent.

We tested whether the missing values or the “don't know" responses may cause any selectivity bias in our sample that is usable for the regression analysis. For this purpose, we generated a dummy variable indicating a missing value (either category 7 or 8 from Table 1) if the firm did not respond properly to the question, and regressed this on all our regressors as decribed below by using a probit model. Of course, this accounts only for selection on observables, but given the large number of covariates we believe that the likelihood for unobserved systematic selectivity is low. All estimated probit models show that the Wald-test on model significance is never indicating any systematic inference. Thus, all coefficients in this model are jointly zero and we conclude that there is no selectivity in the sample due to missing values in the rate of return, and the observations with missing values or “don't know” are dropped from the further analysis.

\section{Figure 1: Distribution of survey responses on the return on sales}

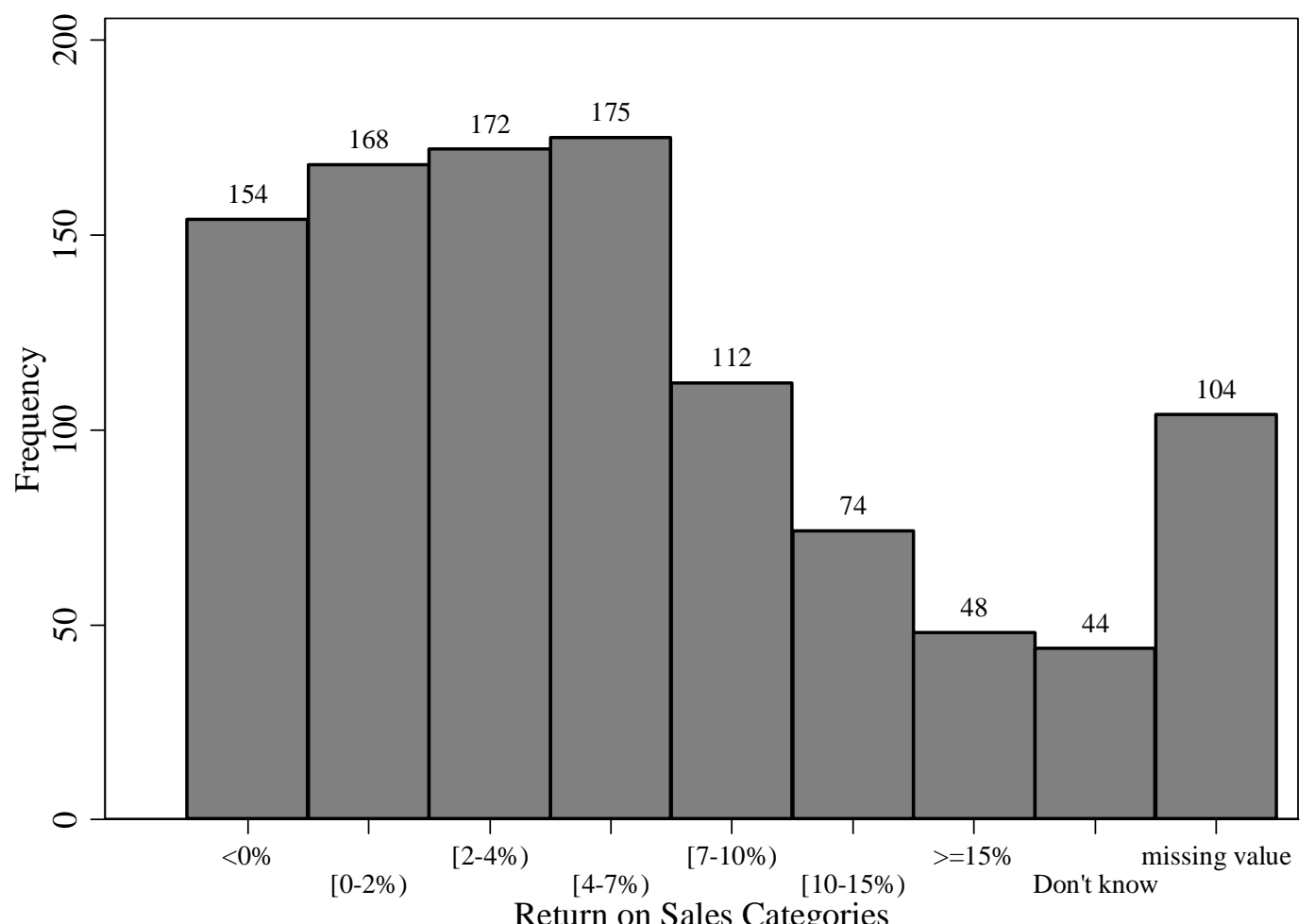




\section{Exogenous variables}

The most important exogenous variables are the spillover measures. For the readers familiar with the CIS questionnaires, we would like to point out that the questions we use are not corresponding to the CIS questions on sources of information, where the respondents are asked if they got any information concerning their innovation activities from a variety of sources and how important they were (without specifying what "important" exactly means in this context). The questions in the 2003 spell of the German innovation survey are more precise. Actually firms where asked to indicate only such kinds of information spillovers that where indispensable for the development of an own product or process.

Based on these responses of the companies, we construct variables standing for incoming spillovers and average spillovers at the industry level indicating outgoing spillovers. Four sources of spillovers are distinguished: competitors, customers, suppliers and research institutions. For each of those sources, we generate a dummy variable for incoming spillovers which has unit value, if the firm reported that it received essential information from this source. Note that the way the questions are posed implies that firms which respond in the affirmative also had the necessary absorptive capacity to make use of the information received.

In the case of spillovers from rivals, it is important to consider outgoing spillovers. As said above in line with other studies, we model outgoing spillovers by computing industry averages of the incoming spillover dummies. These averages are used as indicators of the risk a firm faces that the outcome of its innovation activites partly can be aquired by other parties. The more firms report incoming spillovers, the less valuable is an incoming spillover to one particular recipient in terms of competitive advantage that may ultimately result in a positive mark-up. Clealry every individual firm would benefit much more if it were the only recipient of a spillover. Therefore the two kinds of spillovers, incoming and industry averages, are expected to work into opposite directions with respect to profitability.

Concerning spillovers from suppliers, customers and research institutions the situation is somewhat but not totally different. The individual firm benefits from these information flows if it is the only recipient. If knowledge flows freely in a sector, all 
firms take part of the knowledge spillovers and no company has a specific comparative advantage.

Obviously the internal knowledge stock of a company is an important determinant of profitability. Several studies generate such a stock as (depreciated) sum of past R\&D activities of a firm. As we only have cross-sectional data, we linked our sample to the database of the German Patent and Trademark Office (DPMA) which contains both patent applications filed with the German patent office and with the European Patent Office since 1978. The latter only applies if protection for Germany was requested by the applicant, though. These data enable us to construct a stock of "successful" outcome of $R \& D$ projects for each firm from long time series. We found that $46 \%$ of our observed firms had at least one patent. The patent stock (PS) of firm $i$ in period $t$ is calculated by the perpetual inventory method with a constant depreciation rate as

$$
P S_{i t}=(1-\delta) P S_{i, t-1}+P A_{i t},
$$

where $P A$ is the number of patent applications in year $t$ and $\delta$ is the constant depreciation rate that is set to 15\% (see Griliches and Mairesse, 1984, and Hall, 1990, for more detailed descriptions). Of course, patents are a narrower measure than an $R \& D$ knowledge stock. For that reason we also include R\&D spending as proxy for the nonpatented knowledge stock. ${ }^{5}$ We use the R\&D intensity, RDINT, measured as R\&D divided by sales to avoid multicollinearity with firm size. In order to allow for decreasing returns to scale, we also include a squared term of R\&D intensity.

Other included variables are the share of sales volume exported (EXPORT) at the firm level and the import quota (IMPORT) as well as the Herfindahl concentration index (HERF) at the industry level to measure domestic and international competition. STARTUP denotes that the firm in question has been founded during the last three years. Size effects are considered by the number of employees $(E M P)$. We use the capital intensity (KAPINT) defined as fixed assets divided by the number of employees

\footnotetext{
${ }^{5}$ R\&D expenditure may be a good proxy for the R\&D stock, as adjustment costs of R\&D are usually assumed to be high, as the largest fraction of $R \& D$ cost are wages of $R \& D$ employees. Since laying off R\&D personnel would imply a large loss of knowledge or human capital that cannot easily be recovered by hiring other individuals, it is often stated that firms smooth R\&D spending over time. If this applies, expenditure should be highly correlated with the R\&D stock of a firm.
} 
as a variable that indicates capital requirements. As at least a part of these capital expenditures is sunk, this variable is expected to represent barriers to entry. Ten industry dummies control differences across sectors that may not be captured by the other structural variables. ${ }^{6}$

\section{Timing of exogenous variables}

As mentioned above, we only use data from a single spell of the innovation survey. In order to avoid endogeneity of the right-hand side variables, we use lagged values whenever possible. Basically the survey covers the innovation behavior of firms from the year 2000 to 2002. This, however, applies mainly to the qualitative variables. Variables in monetary units are measured for the year 2002 and 2001. Thus, our dependent variable, return on sales, is measured in $2002(=t)$, and we can make use of one lag for the regressors. Whenever we use data from different sources we use the information up to the year 2000, i.e. two lags, as we then make sure that the data applies to the beginning of the survey period, and risk of endogeneity is even less. The latter applies to the patent stock, the Herfindahl index and the import quotas. Employment, exports, $R \& D$ intensity and capital intensity are measured in $2001(=t-1)$. The dummy variable EAST is time-invariant, STARTUP just indicates a firm that was founded in during the period 2000 to 2002. The spillover measures account for the time window of 2000 to 2002. Descriptive Statistics are presented in Table 2.

\footnotetext{
${ }^{6}$ The Herfindahl index and the import quotas are measured at more detailed industry level than the dummies. Hence, we can include all of these variables without causing identification problems.
} 
Table 2: Descriptive statistics (903 observations) for the year $\boldsymbol{t}=\mathbf{2 0 0 2}$

\begin{tabular}{|c|c|c|c|c|c|}
\hline Variable & Description & Mean & Std. Dev. & Min & Max \\
\hline$\pi / S A L E S(\mathrm{t})$ & Return on Sales in period $t$ & 2.373 & 1.735 & 0 & 6 \\
\hline $\operatorname{IMPORT}(\mathrm{t}-2)$ & Imports (imports/domestic production) & 0.376 & 0.350 & 0.065 & 2.188 \\
\hline$H H I(t-2)$ & Herfindahl index in $\mathrm{t}-2$ & 51.243 & 70.742 & 3.213 & 642.345 \\
\hline$E M P / 1000(\mathrm{t}-1)$ & )Employment (in thsd.) & 0.806 & 3.426 & 0.001 & 41.754 \\
\hline RDINT (t-1) & $\mathrm{R} \& \mathrm{D}$ spending $(\mathrm{t}-1)$ / Sales $(\mathrm{t}-1)$ & 0.039 & 0.063 & 0 & 0.404 \\
\hline$P S / E M P(\mathrm{t}-2)$ & Patent Stock per employee (t-2) & 0.018 & 0.039 & 0 & 0.238 \\
\hline EXPORT (t-1) & Exports (exports in $\mathrm{t}-1$ / sales in $\mathrm{t}-1$ ) & 0.271 & 0.250 & 0 & 1 \\
\hline EAST & Dummy: Eastern German location & 0.323 & 0.468 & 0 & 1 \\
\hline STARTUP & $\begin{array}{l}\text { Dummy: firm founded in recent } 3 \\
\text { years }\end{array}$ & 0.034 & 0.182 & 0 & 1 \\
\hline KAPINT (t-1) & $\begin{array}{l}\text { Capital intensity [physical assets in } \\
\text { million DM (t-1) / employment (t-1)] }\end{array}$ & 0.098 & 0.100 & 0.003 & 0.772 \\
\hline
\end{tabular}

Dummy variables for incoming spillovers

\begin{tabular}{lcccr} 
Competitors & 0.249 & 0.433 & 0 & 1 \\
Customers & 0.604 & 0.489 & 0 & 1 \\
Suppliers & 0.206 & 0.405 & 0 & 1 \\
Research Institutions & 0.140 & 0.347 & 0 & 1 \\
\hline \multicolumn{4}{r}{ Measures of average spillovers (industry } & average of incoming spillovers) \\
Competitors & 0.145 & 0.083 & 0 & 0.667 \\
Customers & 0.363 & 0.165 & 0 & 1 \\
Suppliers & 0.118 & 0.073 & 0 & 0.500 \\
Research Institutions & 0.084 & 0.078 & 0 & 0.500 \\
\hline
\end{tabular}

Note: 10 industry dummies omitted.

\section{Estimation results}

We estimate Ordered Probit models to determine the return on sales. Typically researcher have to estimate the threshold values describing the transition from one category to another. In this case, however, the variance of the model cannot be identified and the interpretation of the estimates is basically limited to the sign of the coefficients and their significance levels. From our survey data, however, we know the actual threshold values for each category (see Table 1), and those do not have to be estimated, which allows us to identify the variance and that, in turn, enables us to interpret the magnitudes of the estimates as the coefficients can be interpreted as marginal effects in a standard linear regression model (see e.g. Verbeek, 2000: 190-194, for a discussion of the Ordered probit model with known threshold values. This model is also referred to as interval regression. See e.g. Wooldridge, 2002: 508). 
As heteroscedasticity in the Ordered Probit model may lead to inconsistency of the coefficient estimates, we conducted LR tests and considered grouwise multiplicative heteroscedasticity of the form $\sigma_{i}=\sigma \exp \left(z_{i}{ }^{\prime} \alpha\right)$, where $\mathrm{z}$ denotes the vector of variables possibly causing heteroscedasticity and $\alpha$ the additional coefficients to be estimated. The heteroscedasticity was initally modelled by the set of industry dummies, EAST and a set of five firm size-class dummies based on employment. The LR statistics rejected the assumption of homoscedasticity, but show that it is sufficient to employ the firm size dummies in the variance equation.

We first estimated an Ordered Probit model only with a constant term. This is instructive as we are able to get an idea of the unconditional distribution of the return on sales, i.e. not from the observed categories but from the underlying latent variable. The average estimated unconditional return on sales amounts to $4.2 \%$ in our sample. The regression results of the full model are shown in Table 3.

Incoming spillovers from competitors' R\&D activities have a positive and industry averages have a negative impact on profits. Thus, as theoretical results predict, spillovers have opposite effects for firms' profitability in dependence of the direction of the information flow. To the best of our knowledge this is the first test on the effects of incoming and outgoing spillovers on firms' profitability. Interestingly, this kind of spillover is the only one with a significant impact. Information from customers, suppliers or research institutions does not affect profitability, although the variables concerning incoming spillovers have only unit value if the firms express that this spillover was indispensable for their own innovation projects. This may indicate the fact that customers, suppliers and research institutions are vertically related to a company, that is, these agents have little incentives to restrict a vertical flow of knowledge to certain firms. Customers will possibly benefit from spillovers to their suppliers with respect to improved products or production materials in the market. Same applies to suppliers where the firm in question is a customer itself. Suppliers would have an incentive to disseminate knowledge to as many customers as possible, as demand for their products may rise. Research institution provide their knowledge to the public domain anyway. An exception may be contract research, though. Thus, one should not expect that spillovers that leak out from vertically related agents have an impact on 
profitability, as this information should, in principle, be available for a broad range of firms, so that typically a single firm has no comparative advantage resulting from such spillovers. For horizontal spill-overs, however, the situation is completely different, as every important piece of information that does not spillover to rivals may result in an own comparative advantage. The more freely knowledge spills over, though, any advantage may be competed away fairly quickly so that profitability levels are adjusted among the firms in the industry. An incoming spillover from a competitor increases the profitability by $1.2 \%$ points, on average. Given that the average profitability is $4.2 \%$ in the sample, this effect just stemming from external resources seems to be large. However, this spillover cannot be seen independently of the outgoing spillovers. If we, for instance, assume a firm is an industry where knowledge spillovers are not flowing freely, say at the $10 \%$ quantile of our sample distribution of competitor spillovers (value equals 0.042 ), the outgoing spillovers would reduce the profits by about $0.4 \%$ points. At the sample median of competitors' outgoing spillovers (=0.146), information leakage would reduce profits by $1.4 \%$ points and would thus roughly neutralize the benefit of incoming spillovers $(=1.2 \%$ points). Firms that are in industries where knowledge is more difficult to appropriate (outgoing spillovers are above median), profits are reduced even more than increased by incoming spillovers. Note that this effect does not point to an inconsistency in the estimation results. If the negative effect of outgoing spillovers is larger than the potential benefit of an incoming spillover, it just means that in these industries the average mark-up level of firms is lower due to high spillover effects to rivals.

Furthermore, we find that $R \& D$, and thus the knowledge stock of a firm as we assume, generates positive returns over a large range of the $R \& D$ distribution. As we allow for decreasing returns to scale, the estimated curve peaks at an R\&D intensity of $8.6 \%$ which is at about the $90 \%$ quantile of the $R \& D$ intensity distribution in the sample. Interestingly, the $10 \%$ of observations located beyond the turning point are dominated by Eastern German firms. They have a high R\&D intensity, but not due to the fact that they are highly innovative and successful. Instead, a lot of R\&D in Eastern Germany is subsidized which was initiated by the German Federal Government after the German reunification in 1990 to foster Eastern Germany’s catching-up process. This situation still persisted in the early 2000s where our data refer to. As a result, Eastern German firms 
show a high level of $R \& D$, but comparatively low sales which drives their $R \& D$ intensity up, but not their profits. See Almus and Czarnitzki (2003) or Czarnitzki and Licht (2006) for a discussion of innovation policy and its effects on innovation input and output in Eastern Germany.

We also find a positive effect of patenting. We interpret this result as a premium that firms can achieve if their $R \& D$ leads to patentable knowledge. In that case the knowledge stock is better protected against rivals if information leaks out, as the knowledge is subject to a legal property right. Although significantly positive, the marginal effect of patenting is low. As one can see in Table 3, the estimated coefficient of PS/EMP is about 10. The average patent stock in about sample is about 25 and average employment is 806. Thus, if the average firm would double its patent stock from 25 to 50, the corresponding increase in return on sales would be $0.31 \%$-points, all else constant. As the average markup amounts to 4.2 in the sample, this increase would correspond to a relative gain of about $7.4 \%$. However, this result should be interpreted with care as the patent distribution is very skew and doubling a firm's patent stock would be a large step. So, the single number we calculated cannot be seen as "representative" patent premium. It rather varies a lot across size of patent stocks and firm size. 
Table 3: Ordered Probit models with known threshold values on return on sales

\begin{tabular}{lcccc}
\hline & \multicolumn{2}{c}{ Model A } & \multicolumn{2}{c}{ Model B } \\
Variable & homoscedastic & heteroscedastic & homoscedastic & heteroscedastic \\
\hline RDINT & 9.563 & 9.693 & 9.120 & 9.344 \\
& $(8.240)$ & $(8.427)$ & $(8.255)$ & $(8.428)$ \\
RDINT ${ }^{2}$ & $-55.899^{* *}$ & $-61.509^{* *}$ & $-56.017^{* *}$ & $-61.191^{* *}$ \\
& $(26.854)$ & $(28.062)$ & $(26.784)$ & $(27.931)$ \\
PS/EMP & $9.974^{* *}$ & $10.117^{* *}$ & $9.943^{* *}$ & $10.174^{* *}$ \\
& $(4.953)$ & $(5.027)$ & $(4.975)$ & $(5.054)$ \\
IMPORT & -0.913 & -0.876 & -1.135 & -1.090 \\
& $(1.005)$ & $(0.993)$ & $(1.046)$ & $(1.034)$ \\
HHI & 0.003 & 0.003 & 0.002 & 0.002 \\
& $(0.003)$ & $(0.003)$ & $(0.003)$ & $(0.003)$ \\
EMP/1000 & $-0.123^{* *}$ & $-0.121^{* *}$ & $-0.123^{* *}$ & $-0.119^{* *}$ \\
& $(0.057)$ & $(0.052)$ & $(0.059)$ & $(0.053)$ \\
EXPORT & 1.098 & 1.162 & 1.143 & 1.174 \\
& $(0.792)$ & $(0.787)$ & $(0.791)$ & $(0.785)$ \\
EAST & -0.252 & -0.250 & -0.217 & -0.211 \\
& $(0.399)$ & $(0.402)$ & $(0.398)$ & $(0.402)$ \\
STARTUP & $-2.005^{* *}$ & $-1.821^{*}$ & $-2.079^{* *}$ & $-1.952^{*}$ \\
& $(1.001)$ & $(1.014)$ & $(0.998)$ & $(1.012)$ \\
KAPINT & $3.898^{* *}$ & $3.546^{*}$ & $3.868^{* *}$ & $3.563^{*}$ \\
& $(1.880)$ & $(1.885)$ & $(1.876)$ & $(1.879)$ \\
\hline
\end{tabular}

Measures of Incoming Spillovers

\begin{tabular}{|c|c|c|c|c|}
\hline Competitiors & $\begin{array}{l}1.178^{* * *} \\
(0.430)\end{array}$ & $\begin{array}{l}1.160^{* * *} \\
(0.419)\end{array}$ & $\begin{array}{l}1.432 \text { *** } \\
(0.448)\end{array}$ & $\begin{array}{l}1.407^{* * *} \\
(0.439)\end{array}$ \\
\hline Customers & & & $\begin{array}{r}-0.443 \\
(0.396)\end{array}$ & $\begin{array}{r}-0.426 \\
(0.395)\end{array}$ \\
\hline Suppliers & & & $\begin{array}{r}-0.760 \\
(0.477)\end{array}$ & $\begin{array}{l}-0.680 \\
(0.468)\end{array}$ \\
\hline Research Institutions & & & $\begin{array}{r}0.374 \\
(0.561)\end{array}$ & $\begin{array}{r}0.321 \\
(0.548)\end{array}$ \\
\hline
\end{tabular}

Measures of Outgoing Spillovers

\begin{tabular}{lcccc}
\hline Competitors & $-10.170^{* * *}$ & $-9.808^{* * *}$ & $-10.445^{* * *}$ & $-9.847^{* * *}$ \\
& $(2.764)$ & $(2.699)$ & $(3.068)$ & $(3.017)$ \\
Customers & & & 2.835 & 2.861 \\
& & & $(1.914)$ & $(1.931)$ \\
Suppliers & & -0.458 & -0.966 \\
& & & $(3.268)$ & $(3.212)$ \\
Research Institutions & & & -3.334 & -3.536 \\
& & & $(3.474)$ & $(3.404)$ \\
\hline Intercept & 4.170 & 4.365 & 4.158 & 4.384 \\
& $(0.891)$ & $(0.874)$ & $(0.917)$ & $(0.901)$ \\
\hline
\end{tabular}


...Table continued

\begin{tabular}{lcccc}
\hline Test on joint significance & $\chi^{2}(10)=$ & $\chi^{2}(10)=$ & $\chi^{2}(10)=$ & $\chi^{2}(10)=$ \\
of industry dummies & $33.54^{* * *}$ & $30.51^{* * *}$ & $30.93^{* * *}$ & $29.00^{* * *}$ \\
\hline Sigma & $1.639^{* * *}$ & $1.808^{* * *}$ & $1.635^{* * *}$ & $1.788^{* * *}$ \\
& $(0.029)$ & $(0.071)$ & $(0.029)$ & $(0.071)$ \\
Test on joint significance & & $\chi^{2}(10)=$ & & $\chi^{2}(5)=$ \\
of variables in & & $13.21^{* *}$ & & $12.74 * *$ \\
heteroscedasticity term & & -1689.939 & -1693.442 & -1687.072 \\
\hline Log-Likelihood & -1696.542 & 75.735 & 84.903 & 82.135 \\
Wald test $\chi^{2}(28)$ & 78.167 & &
\end{tabular}

Note: $* * *(* *, *)$ indicate a significance level of $1 \%(5 \%, 10 \%)$. Standard errors in parentheses. Sigma denotes the estimated standard error.

Our results also point to the conclusion that profits decrease with firm size. Note that we tested also for a non-linear relationship using the square of employment, but that did not turn out to be significant. Size disadvantages have been identified for German data earlier (see Neumann et al., 1979, 1981). We also find that newly founded firms realize lower profits that more experienced firms, on average. Typically, young firms face higher costs to produce the same output as an older firm. Scholars pointed to learning curve effects, that is, the more accumulated output a firm has produced over its life cycle, the more experienced it will be, and thus can achieve same output levels with more efficient factor use as it matures. Finally, we find that capital intensity is positively significant in the regressions (only at the $10 \%$ in the heteroscedastic models, though). We interpret this finding as barriers to entry. High capital intensities in production may prevent new entrants from competing in the same market, and thus firms realize positive mark-ups. The ten industry dummies are jointly significant and thus capture some variation in profits unexplained by the other variables.

\section{Robustness test}

As a robustness check, we split the sample at the median of firm size (= 100 employees) to check if there are differences among small and large firms. It turns out that the results on the spillover variables hold, and that their effects on profits y have about the same magnitude for both small and large companies. All other results basically also hold, but due to smaller sample size, the patent stock becomes insignificant for the smaller firms 
(but sign and magnitude of the coefficient remain similar to the full sample), and the significance level drops to $10 \%$ for the sample of large firms.

\section{Conclusion}

We present the results of an empirical study concerning the impact of spillovers from competitors on profitability. Our major interest is the consideration of differences between incoming and outgoing spillovers. Incoming spillovers have a positive effect, while outgoing ones significantly reduce profits if knowledge flows of rivals are considered. We also establish that only spillovers from competitors exert an effect. While incoming spillovers increase a firm's profits, these benefits are reduced by the degree of total spillovers in an industry. If knowledge flows relatively free among competitors, firms cannot realize high competitive advantages. Spillovers from suppliers, customers or research institutions like universities have no significant impact on profit levels of individual firms. We believe that this is due to the fact that these agents typically have little incentives to restrict potential spillovers to selected firms. Research institutions provide results for the public domain. Suppliers and customers have an incentive to disseminate knowledge to as many potential customers or suppliers, as they will benefit with respect to better or less costly products or materials traded in the market.

Innovative activity in general has positive effects on profitability. Firms investing in $\mathrm{R} \& \mathrm{D}$, and thus maintain higher knowledge stocks, show higher levels of profitability than others. Interestingly, we find that the part of the knowledge stock which is patented, and thus, protected by intellectual property (IP) rights generates a positive mark-up on top of the knowledge stock itself. We believe that this effect is due to the restriction of knowledge transfer to rivals. If rivals want to benefit from patented knowledge, they will have to pay license fees or negotiate other compensations with the inventor. At the very least, competitors would have to "invent around" the IP protected knowledge which would also make imitation more costly and thus reduces the potential profits for third parties.

Our results show that several firms actually benefit from rivals' innovations. This implies that the social return is higher than the private one which is in accordance with 
earlier results based on other models and methods. Given that social returns are larger than the private ones, this study supports the argument for subsidization of firms' R\&D. It would be interesting to investigate in future research, whether governmental institutions really take account of the externalities. Or put it differently, do companies receive subsidies more frequently if the risk of outgoing spillovers is high?

In order to verify our results, it would be desirable to have similar data but in form of panel data available. As we only have a cross-sectional database, we cannot test whether the results are subject to individual firm heterogeneity due to unobserved effects. Panel data would allow to account for firm-specific heterogeneity in profit levels due to management quality or other time-constant factors.

\section{References}

Amir, R. and J. Wooders (2000), One-Way Spillovers, Endogenous Innovator/Imitator Roles, and Research Joint Ventures, Games and Economic Behavior 31, 1-25.

Arrow, K.J. (1962), Economic Welfare and the Allocation of Resources for Invention, in: R.R. Nelson (ed.), The Rate and Direction of Inventive Activity, Princeton: Princeton University Press.

D’Aspremont, C. and A. Jaquemin (1988), Cooperative and Noncooperative R\&D in Duopoly with Spillovers, American Economic Review 78, 1133-1137.

Atallah, G. (2005), R\&D Cooperation with Asymmetric Spillovers, Canadian Journal of Economics 38 (3), 919-936.

Belderbos, R., M. Carree, B. Diederen, B. Lokshin and R. Veugelers (2004), Heterogeneity in R\&D Cooperation Strategies, International Journal of Industrial Organization 22, 1237-1263.

Bernstein, J.I. (1988), Costs of Production, Intra- and Interindustry R\&D Spilllovers: Canadian Evidence, Canadian Journal of Economics 21, 324-347.

Bernstein, J.I. (1989), The Structure of Canadian Inter-Industry R\&D Spillovers and the Rates of Return to R\&D, Journal of Industrial Economics 37, 315-328. 
Bernstein, J.I. and P.A. Mohnen (1994), International R\&D Spillovers Between U.S. and Japanese R\&D Intensive Sectors, NBER Working Paper No. 4682, Cambridge, MA.

Bloom, N., M. Schankerman and J. van Reenen (2005), Identifying Technology Spillovers and Product Market Rivalry, CEP Discussion Paper No 675, London.

Cassiman, B. and R. Veugelers (2002), R\&D Cooperation and Spillovers: Some Empirical Evidence from Belgium, American Economic Review 92, 1169-1184.

Cohen, W.M. and J.P. Walsh (2000), R\&D Spillovers, Appropriability and R\&D Intensity: A Survey Based Approach, Report prepared for the Economic Assessment Office, Advanced Technology Program.

De Bondt, R. and I. Henriques (1995), Strategic Investment with Asymmetric Spillovers, Canadian Journal of Economics 28, 656-674.

Cohen, W.M. and Levinthal, D.A. (1989), Innovation and Learning: The Two Faces of R\&D, Economic Journal 99, 569-596.

Collins, N. and L.E. Preston (1969), Price-Cost Margins and Industry Structure, Review of Economics and Statistics 51, 271-286.

Griliches, Z. (1992), The Search for R\&D Spillovers, Scandinavian Journal of Economics 94, 29-47.

Griliches, Z. (1998), R\&D and Productivity: The Econometric Evidence, Chicago: Chicago University Press.

Hanel, P. and A. St-Pierre (2002), Effects of R\&D Spillovers on the Profitability of Firms, Review of Industrial Organization 20, 305-3222.

Hitt, L. and P. Tambe (2007), Measurement Error and the Estimated Effects of Knowledge Spillovers, unpublished manuscript, The Wharton School, University of Pennsylvania.

Jaffe, A.B. (1986), Techbnological Opportunity and Spillover of R\&D: Evidence from Firms’ Patants, Profits, and Market Value, American Economic Review 76, 984101. 
Nadiri, I.M: (1993), Innovation and Technological Spillovers, NBER Working Paper No. 4423, Cambridge, MA.

Neumann, M., I. Böbel and A. Haid (1979), Profitability, Risk and Market Structure in West German Industries, Journal of Industrial Economics 27, 227-242

Neumann, M., I. Böbel and A. Haid (1981), Market Structure and the Labour Market in West German Industries - A Contribution Towards Interpreting the StructurePerfomance Relationship, Journal of Economics/Zeitschrift für Nationalökonomie 41, 97-109.

Ornaghi, C. (2006), Spillover in Product and Process Innovation: Evidence from Manufacturing Firms, International Journal of Industrial Organization 24, 349380.

Rouvinen, P. (2002), The Existence of R\&D Spillovers: A Cost Function Estimation with Random Coefficients, Economics of Inovation and New Technology 11, 525541.

Schmidt, T. (2005), Knowledge Flows and R\&D Cooperation: Firm-Level Evidence from Germany, ZEW Discussion Paper No. 05-22, Mannheim.

Vandekerckhove, J. and De Bondt, R. (2007), Asymmetric Spillovers and Sequential Stategic Investments, Paper presented at the Conference on Technology and Innovation, Milan (May 2007).

Vencatachellum, D. and B. Versaevel (2006), Horizontal R\&D Cooperation and Spillovers: Evidence from France, Centre National de la Recherche Scientifique: Groupe d’Analyse et de Théorie Économique, Working Paper 06-12, Écully Cedex.

Verbeek, M. (2000), A Guide to Modern Econometrics, Chichester: John Wiley \& Sons. Veugelers, R. and B. Cassiman (2005), R\&D Cooperation between Firms and Universities. Some Empirical Evidence from Belgian Manufacturing, International Journal of Industrial Organization 23, 355-379.

Wooldridge, J.M. (2002), Econometric Analysis of Cross Section and Panel Data, Cambridge: MIT Press. 